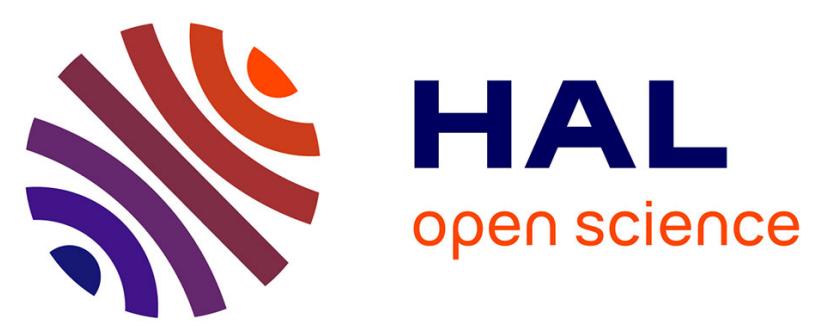

\title{
Idiopathic acute eosinophilic pneumonia demanding ECMO for a teenager smoking tobacco and cannabis
}

Emilie Sauvaget, Jean Dellamonica, Kevin Arlaud, Céline Sanfiorenzo, Gilles

Bernardin, Bernard Padovani, Laurent Viard, Jean-Christophe Dubus

\section{- To cite this version:}

Emilie Sauvaget, Jean Dellamonica, Kevin Arlaud, Céline Sanfiorenzo, Gilles Bernardin, et al.. Idiopathic acute eosinophilic pneumonia demanding ECMO for a teenager smoking tobacco and cannabis. Pediatric Pulmonology, 2010, 45 (12), pp.1246. 10.1002/ppul.21314 . hal-00570702

\section{HAL Id: hal-00570702 \\ https://hal.science/hal-00570702}

Submitted on 1 Mar 2011

HAL is a multi-disciplinary open access archive for the deposit and dissemination of scientific research documents, whether they are published or not. The documents may come from teaching and research institutions in France or abroad, or from public or private research centers.
L'archive ouverte pluridisciplinaire HAL, est destinée au dépôt et à la diffusion de documents scientifiques de niveau recherche, publiés ou non, émanant des établissements d'enseignement et de recherche français ou étrangers, des laboratoires publics ou privés. 


\section{Idiopathic acute eosinophilic pneumonia demanding ECMO for a teenager smoking tobacco and cannabis}

\begin{tabular}{|c|c|}
\hline Journal: & Pediatric Pulmonology \\
\hline Manuscript ID: & PPUL-10-0112.R1 \\
\hline Wiley - Manuscript type: & Case Report \\
\hline $\begin{array}{r}\text { Date Submitted by the } \\
\text { Author: }\end{array}$ & 26-May-2010 \\
\hline Complete List of Authors: & $\begin{array}{l}\text { Sauvaget, Emilie; CHU Timone-Enfants } \\
\text { Dellamonica, Jean; Hôpital I'Archet } \\
\text { Arlaud, Kevin; CHU Timone-Enfants } \\
\text { Sanfiorenzo, Céline; Hôpital l'Archet } \\
\text { Bernardin, Gilles; Hôpital I'Archet } \\
\text { Padovani, Bernard; Hôpital l'Archet } \\
\text { Viard, Laurent; CHU Timone-Enfants } \\
\text { Dubus, Jean-Christophe; CHU Timone-Enfants, Unité de Médecine } \\
\text { Infantile }\end{array}$ \\
\hline Keywords: & $\begin{array}{l}\text { Idiopathic acute eosinophilic pneumonia, tobacco, cannabis, } \\
\text { extracorporeal membrane oxygenation, child }\end{array}$ \\
\hline
\end{tabular}

\section{S ScholarONE" \\ Manuscript Central}




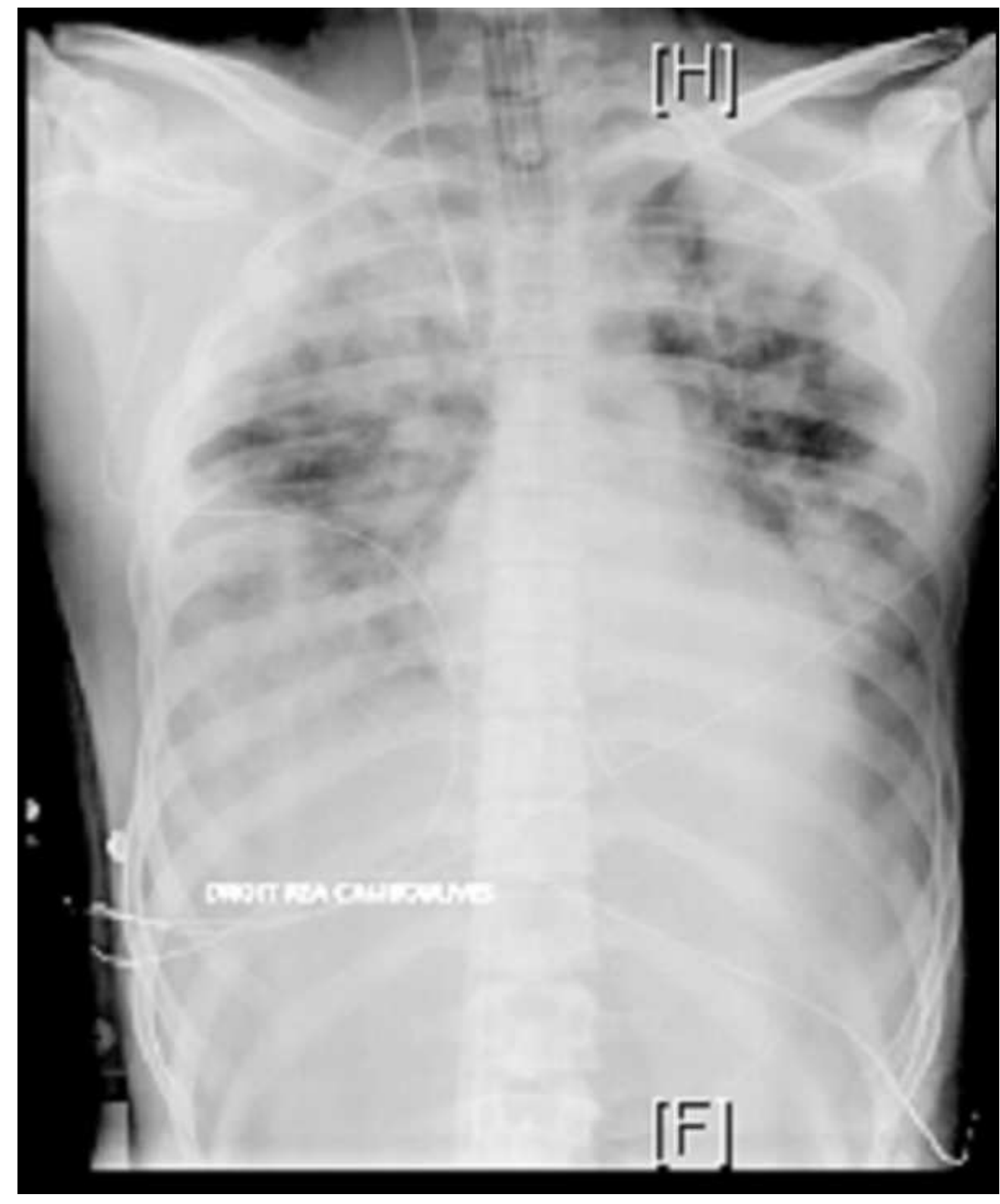

$158 \times 191 \mathrm{~mm}(96 \times 96 \mathrm{DPI})$

John Wiley \& Sons, Inc. 


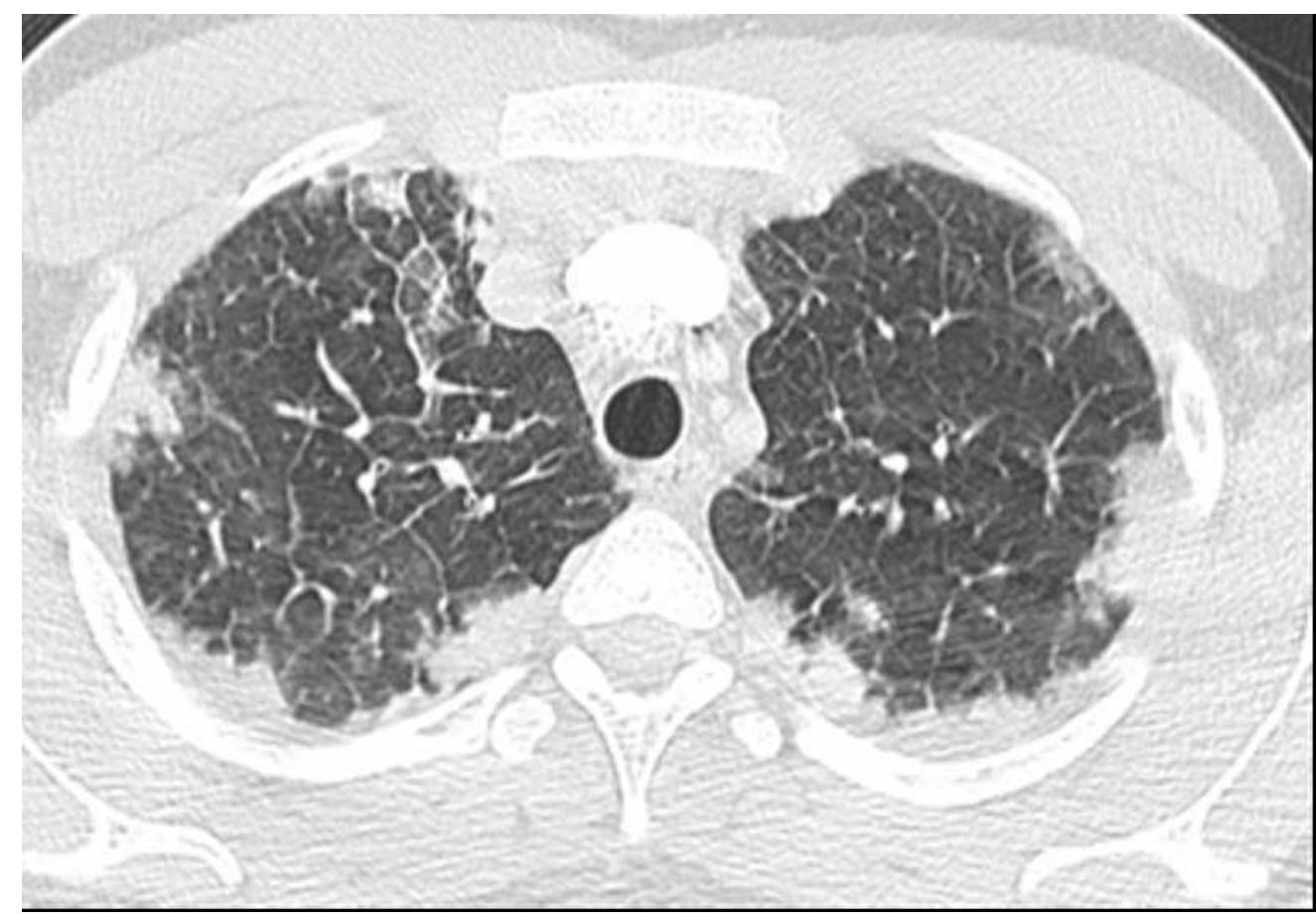

$211 \times 147 \mathrm{~mm}(96 \times 96$ DPI $)$

John Wiley \& Sons, Inc. 


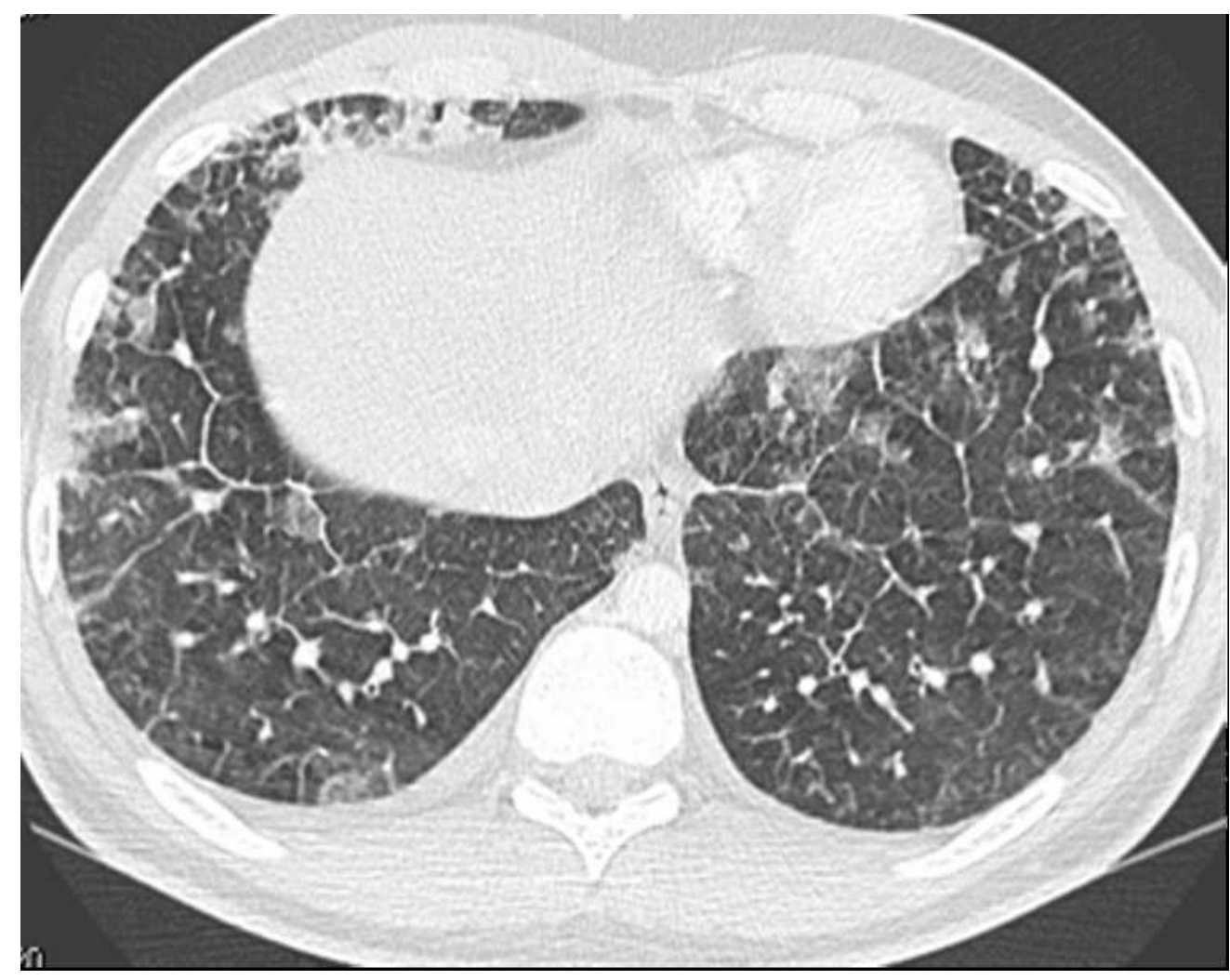

$200 \times 158 m m(96 \times 96$ DPI)

John Wiley \& Sons, Inc. 
Idiopathic acute eosinophilic pneumonia requiring ECMO in a teenager smoking tobacco and cannabis.

Acute eosinophilic pneumonia

Emilie SAUVAGET, MD ${ }^{(1)}$; Jean DELLAMONICA, MD ${ }^{(2)}$; Kévin ARLAUD ${ }^{(1)}$, MD; Céline SANFIORENZO, MD ${ }^{(2)}$; Gilles BERNARDIN, MD, $\mathrm{PhD}^{(2)}$; Bernard PADOVANI, MD, $\mathrm{PhD}^{(3)}$; Laurent VIARD, MD ${ }^{(4)}$; Jean-Christophe DUBUS, MD, $\mathrm{PhD}^{(1,5)}$

${ }^{(1)}$ Pediatric pulmonology unit, University Hospital La Timone-Enfants, Marseille; ${ }^{(2)}$ Medical intensive care unit, L'Archet Hospital and Nice Sophia-Antipolis University, Nice; (3) Department of Radiology, L'Archet Hospital and Nice Sophia-Antipolis University; (4) Medical pediatric intensive care unit, University Hospital La Timone-Enfants, Marseille; ${ }^{(5)}$ CNRS URMITE 6236, Medicine University, Marseille, France

Corresponding Author: Prof Jean-Christophe DUBUS

Unité de Pneumologie et Médecine Infantile CHU Timone-Enfants 13385 Marseille Cedex 05, FRANCE Tel : +33.4.91.38.68.16/ Fax : +33.4.91.38.68.09

E-mail : jean-christophe.dubus@ap-hm.fr

The authors have no conflict of interest concerning this case report

Key words: idiopathic acute eosinophilic pneumonia, tobacco, cannabis, child, extracorporeal membrane oxygenation 


\begin{abstract}
We describe what we believe is an entirely novel case of a 15-year-old boy with idiopathic acute eosinophilic pneumonia and unusual, resistant hypoxaemia which necessitated extracorporeal membrane oxygenation. Response to corticosteroids was excellent and a full recovery was observed. Smoking cigarettes and cannabis on the day the symptoms began may have contributed to the occurrence of this rare disease.
\end{abstract}




\section{Introduction}

Acute eosinophilic pneumonia (AEP) is a rare entity with an incidence of 9.1 per 100,000 person-years which typically affects young men around the age of 30 years. ${ }^{1}$ We report here an extraordinary case of idiopathic AEP in the sense that the patient was young (15 years) and the disease extremely severe, requiring mechanical ventilation and extracorporeal membrane oxygenation (ECMO) and possibly precipitated or exacerbated by smoking tobacco and cannabis.

\section{Case Report}

A teenaged boy aged 15 was admitted to our paediatric intensive care unit with acute respiratory distress syndrome and resistant hypoxaemia requiring ECMO. He had a history of atopy and mild asthma which had resolved symptomatically by the time he was 7 years old. He was exposed to environmental tobacco smoke regularly at home and for the past few months had begun smoking cigarettes occasionally himself. He also reported smoking cannabis for the first time about 3 months prior to admission and on a second occasion just a few hours before the onset of his current respiratory symptoms. He was in contact at home with budgerigars and a dog, and had been working for the past 5 months as a garage mechanic.

24 hours before his admission he had woken up with a fever $\left(38.4^{\circ} \mathrm{C}\right)$ accompanied by asthenia and odynophagia but no respiratory symptoms. He took some paracetamol. Later on in the afternoon, according to his family he smoked cannabis for the second time in 3 months. As the evening and night progressed he developed rapidly deteriorating respiratory distress, chest tightness and orthopnoea which led him to visit the emergency ward of a nearby hospital. On arrival he was noted to be febrile, anxious and hypoxic (pulse oximetry 85\% saturation on room air). Despite nasal oxygen therapy and ad hoc antibiotic therapy with cefotaxime he failed to improve and remained significantly hypoxaemic (pulse oximetry 
$90 \%$ ) even when administered 201 of oxygen by face mask. He was therefore transferred to the intensive care unit. Arterial blood gases showed $\mathrm{pH} 7.34, \mathrm{P}_{\mathrm{a}} \mathrm{O}_{2} 117 \mathrm{mmHg}, \mathrm{P}_{\mathrm{a}} \mathrm{CO}_{2} 42$ mmHg. A chest X-ray showed bilateral alveolar and interstitial infiltrates (Figure 1). Because of the progression of the respiratory distress and the appearance of haemodynamic instability, he was intubated and commenced on ventilatory support with $\mathrm{P}_{\mathrm{a}} \mathrm{O}_{2} / \mathrm{F}_{\mathrm{i}} \mathrm{O}_{2}$ ratio $77 \mathrm{mmHg}$ and PEEP at $10 \mathrm{cmH}_{2} \mathrm{O}$. Noradrenaline was commenced and anti-infectious therapy widened with cefotaxime, levofloxacin, trimethoprim-sulphamethoxazole and amphotericin B.

Meanwhile other extensive tests were performed. The white cell count was $22 \times 10^{9} / \mathrm{L}$ with $0.2 \times 10^{9} / \mathrm{L}$ eosinophils, C-reactive protein $221 \mathrm{mg} / \mathrm{L}$ and procalcitonin $0.87 \mathrm{ng} / \mathrm{ml}$. The procalcitonin control was $1.35 \mathrm{ng} / \mathrm{ml}$. The brain natriuretic peptide was $44 \mathrm{pg} / \mathrm{ml}$. Nasopharyngeal aspiration did not reveal RSV or A and B influenza viruses. Serology (influenza A, B, HIV, Mycoplasma, Chlamydia and Legionella) eventually proved negative. Blood cultures remained sterile. Urinary Legionella pneumophila and Streptococcus pneumoniae antigens were negative. Complement and immunoglobulin assays were normal. There were no signs of immune dysregulation (normal lymphocyte typing, negative antinuclear and anticytoplasmic antibodies, negative anti-MPO and anti-PR3 ANA and no paraprotein). A CT scan of the thorax confirmed mixed reticular and alveolar bilateral pulmonary infiltrates concentrated sub-pleurally with ground-glass opacification and pleural effusions consistent with an acute eosinophilic pneumonia (Figure 2). Bronchoalveolar lavage returned pinkish fluid with 350000 cells $/ \mathrm{mm}^{3}$ (38\% eosinophils, 28\% macrophages, 16\% lymphocytes, $18 \%$ neutrophils). There was no evidence of parasitic, fungal, bacterial or viral infection.

The patient developed a refractory hypoxaemia $\left(\mathrm{pH} 7.38, \mathrm{P}_{\mathrm{a}} \mathrm{O}_{2} 69.1 \mathrm{mmHg}, \mathrm{P}_{\mathrm{a}} \mathrm{CO}_{2} 46.7\right.$ $\left.\mathrm{mmHg}, \mathrm{HCO}_{3}^{-} 26.8 \mathrm{mmol} / \mathrm{L}, \mathrm{SaO}_{2} 95 \%\right)$ despite 90\% $\mathrm{FiO}_{2}$, high PEEP $\left(12 \mathrm{cmH}_{2} \mathrm{O}\right)$ and inhaled nitrogen monoxide. Extracorporeal membrane oxygenation (ECMO) was therefore 
contemplated and the patient transferred to our paediatric intensive care unit where it was instituted.

On his arrival further investigations were performed but there was no evidence of viral (EBV, CMV, HSV, enterovirus, metapneumovirus, RSV, influenza A and B, rhinovirus, adenovirus), bacterial (negative PCR and serology for Chlamydia pneumoniae and psittaci, negative blood cultures), parasitic (Toxoplasma PCR, Toxocara, Bilharzia, Trichinella, Fasciola hepatica and Farmers' lung serology all negative, no amoebae), or fungal infection (Aspergillus serology and RAST, Candida PCR all negative). Blood count continued to show a marked eosinophilic leukocytosis (white cell count $31 \times 10^{9} / \mathrm{L}$ of which $10 \%$ eosinophils). A second bronchoalveolar lavage showed 180,000 cells $/ \mathrm{mm}^{3}$ with $20 \%$ eosinophils, $31 \%$ macrophages, $23 \%$ lymphocytes and $20 \%$ neutrophils and no microorganisms. On the basis of these data a diagnosis of idiopathic AEP was made and the patient commenced on methylprednisolone $4 \mathrm{mg} / \mathrm{kg} /$ day within 24 hours of the onset of the respiratory symptoms. The hypoxaemia improved rapidly (within 24 hours) allowing ECMO weaning after 48 hours and extubation on the fifth day. The following day the patient was transferred from intensive care back to the paediatric pulmonology unit. Oxygen therapy was discontinued within 24 hours by which time the chest X-ray had normalised. Corticosteroid was switched from systemic to oral and tailed off over 3 months. The patient was discharged on the $15^{\text {th }}$ day after admission feeling well and clinically normal. He remained asymptomatic and clinically normal 3 months after discontinuing corticosteroid.

\section{Discussion}

We here report a particularly severe case of idiopathic AEP which, to the best of our knowledge, is the only published case requiring ECMO therapy.

AEP is a rare disease in childhood. ${ }^{2}$ Diagnosis is based on an association of characteristic features including acute respiratory failure with fever, bilateral infiltrates on the chest X-ray, 
severe hypoxemia with blood oxygen saturation $<90 \%$ by pulse oximetry or $\mathrm{P}_{\mathrm{a}} \mathrm{O}_{2}<60 \mathrm{mmHg}$ on room air or $\mathrm{P}_{\mathrm{a}} \mathrm{O}_{2} / \mathrm{FiO}_{2} \leq 300 \mathrm{mmHg}$, "eosinophilic lung" with bronchoalveolar lavage fluid leukocytes $>25 \%$ eosinophils or a predominant eosinophilic infiltrate in lung biopsies in the absence of any identifiable aetiology (infection, allergy, toxic exposure to drugs). ${ }^{3}$ Our case illustrates that the initial chest X-ray may suggest the diagnosis, showing diffuse, interstitial pulmonary infiltrates and sometimes interstitial oedema with Kerley B lines or pleural effusion accompanied by blood hypereosinophilia, although these features are not diagnostic in isolation. Histological confirmation of the diagnosis is not necessary when the bronchoalveolar lavage fluid shows hypereosinophilia in a context of acute febrile dyspnoea. The physiopathology of AEP is not well understood. It appears to result from damage caused by eosinophils infiltrating the lung parenchyma and releasing toxic substances such as basic proteins, lipid mediators and cytokines. Although the precise mechanisms which induce this infiltration in AEP have not yet been fully uncovered, it is sometimes possible to identify putative causative agents or trigger factors which initiate the process. Occasionally no such agent is apparent, in which case the disease is labelled "idiopathic". 2,4 The plethora of presumptive causative agents includes : drugs (antibiotics such as nitrofurantoin, clarithromycin, dapsone and minocycline; chemotherapeutic agents such as methotrexate, bleomycin and fludarabine; non-steroidal anti-inflammatory drugs; amiodarone; phenytoin; captopril); inhalation of dust, smoke or toxins (acetylene, firework smoke, nickel dust, heroin and cocaine); respiratory infections such as aspergillosis and coccidioidomycosis. Tobacco is frequently cited as a possible co-factor, especially soon (within 3 months) after commencing smoking or on resuming smoking after a period of abstinence. In the case of our teenage patient, one might hypothesise that his taking up smoking on a background of environmental tobacco smoke exposure and possible noxious inhalations while working in a garage may have played a part. The fact that he had smoked cannabis just prior to the onset of his 
respiratory symptoms also made us wonder whether this might also have been a factor in triggering the disease, either through an effect of the cannabis itself or toxins admixed with the resin or contaminants such as fungus. In the event we were unable to investigate our patient's cannabis for the presence of such substances.

Approximately two thirds of patients with AEP require mechanical ventilation because of acute respiratory distress, but once the diagnosis is made it can be treated successfully with corticosteroid commencing with a high intravenous dosage then switching to oral dosing while tailing off. ${ }^{5}$ The optimal regimen and duration of corticosteroid therapy is uncertain and has not been characterised in trials: courses of between 2 and 12 weeks' duration have been reported to be equally effective. The sensitivity of the disease to corticosteroid therapy is characteristically spectacular: the clinical, radiological and functional abnormalities, along with the alveolar eosinophilia all resolve rapidly. Recurrence is not described. 


\section{References}

1. Shorr AF, Scoville SL, Cersovsky SB, et al. Acute eosinophilic pneumonia among US Military personnel deployed in or near Iraq. JAMA 2004;292:2997-3005.

2. Oermann CM, Panesar KS, Langston C, et al. Pulmonary infiltrates with eosinophilia syndromes in children. J Pediatr 2000;136:351-358.

3. Philit F, Etienne-Mastroianni B, Parrot A, et al. Idiopathic acute eosinophilic pneumonia: a study of 22 patients. Am J Respir Crit Care Med 2002;166:1235-1239.

4. Navaravong L, Wudhikarn K, Marini JJ. Cigarettes-induced acute eosinophilic pneumonia: case report. Cases Journal 2008;I:414.

5. Vahid B, Marik PE. An 18-year-old woman with fever, diffuse pulmonary opacities, and rapid onset of respiratory failure. Chest 2006;130:1938-1941. 
Idiopathic acute eosinophilic pneumonia requiring ECMO in a teenager smoking tobacco and cannabis.

Acute eosinophilic pneumonia

Emilie SAUVAGET, MD ${ }^{(1)}$; Jean DELLAMONICA, MD ${ }^{(2)}$; Kévin ARLAUD ${ }^{(1)}$, MD; Céline SANFIORENZO, MD ${ }^{(2)}$; Gilles BERNARDIN, MD, $\mathrm{PhD}^{(2)}$; Bernard PADOVANI, MD, $\mathrm{PhD}^{(3)}$; Laurent VIARD, MD ${ }^{(4)}$; Jean-Christophe DUBUS, MD, $\mathrm{PhD}^{(1,5)}$

${ }^{(1)}$ Pediatric pulmonology unit, University Hospital La Timone-Enfants, Marseille; ${ }^{(2)}$ Medical intensive care unit, L'Archet Hospital and Nice Sophia-Antipolis University, Nice; (3) Department of Radiology, L'Archet Hospital and Nice Sophia-Antipolis University; (4) Medical pediatric intensive care unit, University Hospital La Timone-Enfants, Marseille; ${ }^{(5)}$ CNRS URMITE 6236, Medicine University, Marseille, France

Corresponding Author: Prof Jean-Christophe DUBUS

Unité de Pneumologie et Médecine Infantile CHU Timone-Enfants 13385 Marseille Cedex 05, FRANCE Tel : +33.4.91.38.68.16/ Fax : +33.4.91.38.68.09

E-mail : jean-christophe.dubus@ap-hm.fr

The authors have no conflict of interest concerning this case report

Key words: idiopathic acute eosinophilic pneumonia, tobacco, cannabis, child, extracorporeal membrane oxygenation 


\begin{abstract}
We describe what we believe is an entirely novel case of a 15-year-old boy with idiopathic acute eosinophilic pneumonia and unusual, resistant hypoxaemia which necessitated extracorporeal membrane oxygenation. Response to corticosteroids was excellent and a full recovery was observed. Smoking cigarettes and cannabis on the day the symptoms began may have contributed to the occurrence of this rare disease.
\end{abstract}




\section{Introduction}

Acute eosinophilic pneumonia (AEP) is a rare entity with an incidence of 9.1 per 100,000 person-years which typically affects young men around the age of 30 years. ${ }^{1}$ We report here an extraordinary case of idiopathic AEP in the sense that the patient was young (15 years) and the disease extremely severe, requiring mechanical ventilation and extracorporeal membrane oxygenation (ECMO) and possibly precipitated or exacerbated by smoking tobacco and cannabis.

\section{Case Report}

A teenaged boy aged 15 was admitted to our paediatric intensive care unit with acute respiratory distress syndrome and resistant hypoxaemia requiring ECMO. He had a history of atopy and mild asthma which had resolved symptomatically by the time he was 7 years old. He was exposed to environmental tobacco smoke regularly at home and for the past few months had begun smoking cigarettes occasionally himself. He also reported smoking cannabis for the first time about 3 months prior to admission and on a second occasion just a few hours before the onset of his current respiratory symptoms. He was in contact at home with budgerigars and a dog, and had been working for the past 5 months as a garage mechanic.

24 hours before his admission he had woken up with a fever $\left(38.4^{\circ} \mathrm{C}\right)$ accompanied by asthenia and odynophagia but no respiratory symptoms. He took some paracetamol. Later on in the afternoon, according to his family he smoked cannabis for the second time in 3 months. As the evening and night progressed he developed rapidly deteriorating respiratory distress, chest tightness and orthopnoea which led him to visit the emergency ward of a nearby hospital. On arrival he was noted to be febrile, anxious and hypoxic (pulse oximetry 85\% saturation on room air). Despite nasal oxygen therapy and ad hoc antibiotic therapy with cefotaxime he failed to improve and remained significantly hypoxaemic (pulse oximetry 
$90 \%$ ) even when administered 201 of oxygen by face mask. He was therefore transferred to the intensive care unit. Arterial blood gases showed $\mathrm{pH} 7.34, \mathrm{P}_{\mathrm{a}} \mathrm{O}_{2} 117 \mathrm{mmHg}, \mathrm{P}_{\mathrm{a}} \mathrm{CO}_{2} 42$ mmHg. A chest X-ray showed bilateral alveolar and interstitial infiltrates (Figure 1). Because of the progression of the respiratory distress and the appearance of haemodynamic instability, he was intubated and commenced on ventilatory support with $\mathrm{P}_{\mathrm{a}} \mathrm{O}_{2} / \mathrm{F}_{\mathrm{i}} \mathrm{O}_{2}$ ratio $77 \mathrm{mmHg}$ and PEEP at $10 \mathrm{cmH}_{2} \mathrm{O}$. Noradrenaline was commenced and anti-infectious therapy widened with cefotaxime, levofloxacin, trimethoprim-sulphamethoxazole and amphotericin B.

Meanwhile other extensive tests were performed. The white cell count was 22 x $10^{9} / \mathrm{L}$ with $0.2 \times 10^{9} / \mathrm{L}$ eosinophils, C-reactive protein $221 \mathrm{mg} / \mathrm{L}$ and procalcitonin $0.87 \mathrm{ng} / \mathrm{ml}$. The procalcitonin control was $1.35 \mathrm{ng} / \mathrm{ml}$. The brain natriuretic peptide was $44 \mathrm{pg} / \mathrm{ml}$. Nasopharyngeal aspiration did not reveal RSV or A and B influenza viruses. Serology (influenza A, B, HIV, Mycoplasma, Chlamydia and Legionella) eventually proved negative. Blood cultures remained sterile. Urinary Legionella pneumophila and Streptococcus pneumoniae antigens were negative. Complement and immunoglobulin assays were normal. There were no signs of immune dysregulation (normal lymphocyte typing, negative antinuclear and anticytoplasmic antibodies, negative anti-MPO and anti-PR3 ANA and no paraprotein). A CT scan of the thorax confirmed mixed reticular and alveolar bilateral pulmonary infiltrates concentrated sub-pleurally with ground-glass opacification and pleural effusions consistent with an acute eosinophilic pneumonia (Figure 2). Bronchoalveolar lavage returned pinkish fluid with 350000 cells $/ \mathrm{mm}^{3}$ (38\% eosinophils, 28\% macrophages, 16\% lymphocytes, $18 \%$ neutrophils). There was no evidence of parasitic, fungal, bacterial or viral infection.

The patient developed a refractory hypoxaemia $\left(\mathrm{pH} 7.38, \mathrm{P}_{\mathrm{a}} \mathrm{O}_{2} 69.1 \mathrm{mmHg}, \mathrm{P}_{\mathrm{a}} \mathrm{CO}_{2} 46.7\right.$ $\left.\mathrm{mmHg}, \mathrm{HCO}_{3}{ }^{-} 26.8 \mathrm{mmol} / \mathrm{L}, \mathrm{SaO}_{2} 95 \%\right)$ despite 90\% $\mathrm{FiO}_{2}$, high PEEP $\left(12 \mathrm{cmH}_{2} \mathrm{O}\right)$ and inhaled nitrogen monoxide. Extracorporeal membrane oxygenation (ECMO) was therefore 
contemplated and the patient transferred to our paediatric intensive care unit where it was instituted.

On his arrival further investigations were performed but there was no evidence of viral (EBV, CMV, HSV, enterovirus, metapneumovirus, RSV, influenza A and B, rhinovirus, adenovirus), bacterial (negative PCR and serology for Chlamydia pneumoniae and psittaci, negative blood cultures), parasitic (Toxoplasma PCR, Toxocara, Bilharzia, Trichinella, Fasciola hepatica and Farmers' lung serology all negative, no amoebae), or fungal infection (Aspergillus serology and RAST, Candida PCR all negative). Blood count continued to show a marked eosinophilic leukocytosis (white cell count $31 \times 10^{9} / \mathrm{L}$ of which $10 \%$ eosinophils). A second bronchoalveolar lavage showed 180,000 cells $/ \mathrm{mm}^{3}$ with $20 \%$ eosinophils, $31 \%$ macrophages, $23 \%$ lymphocytes and $20 \%$ neutrophils and no microorganisms. On the basis of these data a diagnosis of idiopathic AEP was made and the patient commenced on methylprednisolone $4 \mathrm{mg} / \mathrm{kg} /$ day within 24 hours of the onset of the respiratory symptoms. The hypoxaemia improved rapidly (within 24 hours) allowing ECMO weaning after 48 hours and extubation on the fifth day. The following day the patient was transferred from intensive care back to the paediatric pulmonology unit. Oxygen therapy was discontinued within 24 hours by which time the chest X-ray had normalised. Corticosteroid was switched from systemic to oral and tailed off over 3 months. The patient was discharged on the $15^{\text {th }}$ day after admission feeling well and clinically normal. He remained asymptomatic and clinically normal 3 months after discontinuing corticosteroid.

\section{Discussion}

We here report a particularly severe case of idiopathic AEP which, to the best of our knowledge, is the only published case requiring ECMO therapy.

AEP is a rare disease in childhood. ${ }^{2}$ Diagnosis is based on an association of characteristic features including acute respiratory failure with fever, bilateral infiltrates on the chest X-ray, 
severe hypoxemia with blood oxygen saturation $<90 \%$ by pulse oximetry or $\mathrm{P}_{\mathrm{a}} \mathrm{O}_{2}<60 \mathrm{mmHg}$ on room air or $\mathrm{P}_{\mathrm{a}} \mathrm{O}_{2} / \mathrm{FiO}_{2} \leq 300 \mathrm{mmHg}$, "eosinophilic lung" with bronchoalveolar lavage fluid leukocytes $>25 \%$ eosinophils or a predominant eosinophilic infiltrate in lung biopsies in the absence of any identifiable aetiology (infection, allergy, toxic exposure to drugs). ${ }^{3}$ Our case illustrates that the initial chest X-ray may suggest the diagnosis, showing diffuse, interstitial pulmonary infiltrates and sometimes interstitial oedema with Kerley B lines or pleural effusion accompanied by blood hypereosinophilia, although these features are not diagnostic in isolation. Histological confirmation of the diagnosis is not necessary when the bronchoalveolar lavage fluid shows hypereosinophilia in a context of acute febrile dyspnoea. The physiopathology of AEP is not well understood. It appears to result from damage caused by eosinophils infiltrating the lung parenchyma and releasing toxic substances such as basic proteins, lipid mediators and cytokines. Although the precise mechanisms which induce this infiltration in AEP have not yet been fully uncovered, it is sometimes possible to identify putative causative agents or trigger factors which initiate the process. Occasionally no such agent is apparent, in which case the disease is labelled "idiopathic". 2,4 The plethora of presumptive causative agents includes : drugs (antibiotics such as nitrofurantoin, clarithromycin, dapsone and minocycline; chemotherapeutic agents such as methotrexate, bleomycin and fludarabine; non-steroidal anti-inflammatory drugs; amiodarone; phenytoin; captopril); inhalation of dust, smoke or toxins (acetylene, firework smoke, nickel dust, heroin and cocaine); respiratory infections such as aspergillosis and coccidioidomycosis. Tobacco is frequently cited as a possible co-factor, especially soon (within 3 months) after commencing smoking or on resuming smoking after a period of abstinence. In the case of our teenage patient, one might hypothesise that his taking up smoking on a background of environmental tobacco smoke exposure and possible noxious inhalations while working in a garage may have played a part. The fact that he had smoked cannabis just prior to the onset of his 
respiratory symptoms also made us wonder whether this might also have been a factor in triggering the disease, either through an effect of the cannabis itself or toxins admixed with the resin or contaminants such as fungus. In the event we were unable to investigate our patient's cannabis for the presence of such substances.

Approximately two thirds of patients with AEP require mechanical ventilation because of acute respiratory distress, but once the diagnosis is made it can be treated successfully with corticosteroid commencing with a high intravenous dosage then switching to oral dosing while tailing off. ${ }^{5}$ The optimal regimen and duration of corticosteroid therapy is uncertain and has not been characterised in trials: courses of between 2 and 12 weeks' duration have been reported to be equally effective. The sensitivity of the disease to corticosteroid therapy is characteristically spectacular: the clinical, radiological and functional abnormalities, along with the alveolar eosinophilia all resolve rapidly. Recurrence is not described. 


\section{References}

1. Shorr AF, Scoville SL, Cersovsky SB, et al. Acute eosinophilic pneumonia among US Military personnel deployed in or near Iraq. JAMA 2004;292:2997-3005.

2. Oermann CM, Panesar KS, Langston C, et al. Pulmonary infiltrates with eosinophilia syndromes in children. J Pediatr 2000;136:351-358.

3. Philit F, Etienne-Mastroianni B, Parrot A, et al. Idiopathic acute eosinophilic pneumonia: a study of 22 patients. Am J Respir Crit Care Med 2002;166:1235-1239.

4. Navaravong L, Wudhikarn K, Marini JJ. Cigarettes-induced acute eosinophilic pneumonia: case report. Cases Journal 2008;I:414.

5. Vahid B, Marik PE. An 18-year-old woman with fever, diffuse pulmonary opacities, and rapid onset of respiratory failure. Chest 2006;130:1938-1941. 
Figure 1: Chest X-ray showing bilateral alveolar and interstitial infiltrates

Figure 2: CT-scan of the thorax showing bilateral sub-pleural condensations and septal thickening in the upper pulmonary lobes (Fig 2A), and diffuse ground-glass opacities, with septal thickening in the lower pulmonary lobes, with presence of pleural fluid in the right lobe (Fig 2B). 
Figure 1: Chest X-ray showing bilateral alveolar and interstitial infiltrates

Figure 2: CT-scan of the thorax showing bilateral sub-pleural condensations and septal thickening in the upper pulmonary lobes (Fig 2A), and diffuse ground-glass opacities, with septal thickening in the lower pulmonary lobes, with presence of pleural fluid in the right lobe (Fig 2B). 